\title{
Promoting protean career through employability culture and mentoring: career strategies as moderator
}

\begin{abstract}
Purpose: The purpose of this paper is to examine the effects of organizational-related variables and the moderating role of career strategies on protean career among employees.

Design/methodology/approach: Research data are gathered from a sample of 306 employees in 18 electrical and electronics multinational corporations (MNCs) in Malaysia. Partial least squares structural equation modeling (PLS-SEM) is used to examine the influences of organizational-related factors and the moderating role of career strategies on protean career.
\end{abstract}

Findings: The results demonstrate that organizational-related variables, namely, employability culture and mentoring are viewed as potential predictors of protean career. There are significant moderating effects of career strategies on the relationship between both employability culture and mentoring toward protean career among employees.

Research limitations/implications: This paper provides an empirical framework to explain protean career based on the review of career-related literatures.

Practical implications: The findings provide implications to both organizations and human resource development practitioners on new career trends of protean career. Practical interventions are suggested to assist individuals and organizations toward protean career development.

Originality/value: This paper offers new insight into the predicting factors of protean career and its moderating role on career strategies.

Keyword: Mentoring; Protean career; Organizational; Career strategies; Employability culture; Moderator 